Article

\title{
Temporal Variability and Characterization of Aerosols across the Pakistan Region during the Winter Fog Periods
}

\author{
Muhammad Fahim Khokhar ${ }^{1,2, *}$, Naila Yasmin ${ }^{1}$, Farrukh Chishtie ${ }^{3}$ and Imran Shahid ${ }^{3}$ \\ 1 Institute of Environmental Sciences and Engineering, National University of Sciences and Technology, \\ Islamabad 44000, Pakistan; nailayasmin@gmail.com \\ 2 Max-Planck-Institute for Chemistry, Mainz 55128, Germany \\ 3 Institute of Space and Technology, Islamabad 44000, Pakistan; farrukh.chishtie@gmail.com (F.C.); \\ imran.shaahid@gmail.com (I.S.) \\ * Correspondence: fahim.khokhar@iese.nust.edu.pk; Tel.: +92-51-9085-4308
}

Academic Editors: Shinji Wakamatsu and Shiro Hatakeyama

Received: 29 February 2016; Accepted: 22 April 2016; Published: 16 May 2016

\begin{abstract}
Fog is a meteorological/environmental phenomenon which happens across the Indo-Gangetic Plains (IGP) and leads to significant social and economic problems, especially posing significant threats to public health and causing disruptions in air and road traffic. Meteorological stations in Pakistan provide limited information regarding fog episodes as these provide only point observations. Continuous monitoring, as well as a spatially coherent picture of fog distribution, is possible through the use of satellite observations. This study focuses on the 2012-2015 winter fog episodes over the Pakistan region using the Moderate Resolution Image Spectrometer (MODIS), the Ozone Monitoring Instrument and the Cloud-Aerosol Lidar and Infrared Pathfinder Satellite Observations (CALIPSO) products. The main objective of the study was to map the spatial distribution of aerosols, their types, and to identify the aerosol origins during special weather conditions like fog in Pakistan. The study also included ground monitoring of particulate matter (PM) concentrations, which were conducted during the 2014-2015 winter period only. Overall, this study is part of a multi-country project supported by the International Centre for Integrated Mountain Development (ICIMOD), started in 2014-2015 winter period, whereby scientists from Bangladesh, India and Nepal have also conducted measurements at their respective sites. A significant correlation between MODIS (AOD) and AERONET Station (AOD) data from Lahore was identified. Mass concentration of $\mathrm{PM}_{10}$ at all sampling sites within Lahore city exceeded the National Environmental Quality Standards (NEQS) levels on most of the occasions. Smoke and absorbing aerosol were found to be major constituents of winter fog in Pakistan. Furthermore, an extended span of winter fog was also observed in Lahore city during the winter of 2014-2015. The Vertical Feature Mask (VFM) provided by CALIPSO satellite confirmed the low-lying aerosol layers, instead of clouds for the vertical profiles of selected case studies.
\end{abstract}

Keywords: AOD; MODIS; AERONET; HYSPLIT; IGP; Pakistan

\section{Introduction}

An increasing trend in fog frequencies over South Asia has been observed during the winter season for the last few decades, which has resulted in large disruptions in the daily lives of people across the region [1]. Winter fog creates huge economic losses comparable to other extreme weather events such as hurricanes, storms, and tornadoes [2]. For instance, fog leads to poor visibility which hinders all means of transportation on a massive scale [1].

Light wind, clear sky, high moisture and stable atmospheric conditions are more suitable for fog formation $[3,4]$. Soil moisture is also considered as an important factor in remote sensing for 
fog monitoring [5]. In Pakistan, the Indus River and its tributaries along with soil moisture are considered as major sources air moisture and provide favourable conditions for fog formation. Additionally, large-scale dynamics play a vital role as El Nino conditions in the year 2004 influenced greater air pressure over Pakistan, increasing stability and resulting in favourable conditions for fog during winter months [1].

Atmospheric aerosols are considered as a vital part of the energy balance system of Earth. As being one of the most important components of the atmosphere, they act as a seed for cloud/fog formation, resulting in precipitation. While an increase in their concentration in the atmosphere also causes negative effects on different natural processes: suppression of the precipitation rate of clouds, reduction of visibility and the cause of various health impacts [6-10]. Persistent fog happens over Pakistan during each winter, with high air pollution as a leading factor. Industrialization, urbanization, coal-based power generation, vehicular emissions and biomass burning are the main sources of air pollutants [11-13]. Fog also persists when large concentrations of aerosols are present, which characterize a low activation super saturation point [14]. When aerosol loads are elevated, they are considered to be an important factor contributing to persistent fog episodes. The increasing trend in fog occurrence over urban cities has been observed as mainly caused by a high pollution load resulting from multiple sources [15].

Aerosols cause smog, air pollution $[13,16]$ and various impacts on cloud microphysics, global carbon, sulfur, nitrogen and hydrological cycles in both direct and indirect ways [17-19], and originate from sources with different properties [20]. Different types of aerosols have diverse properties on the symbol and extent of aerosol radiative forcing [21]. Black Carbon (BC) is considered as an absorbing aerosol that contributes to global warming $[22,23]$ and the extent of its impact varies in different parts of the world [22,23]. Suspended dust particles alter the propagation of short and long wave radiation through atmospheric scattering and absorption methods [24] and warm the atmosphere due to absorption [25]. Aerosol also have impacts on social aspects like human health and ecological processes [26].

Satellite remote sensing is an emerging field for global atmospheric monitoring of different parameters and their impact on climate, such as aerosols [27,28]. Various studies have been conducted to explore aerosol trends [29-34] and their effects at both the global and regional scales [35,36] by utilizing satellite instruments. Additionally, AOD using AERONET data over the Lahore and Karachi stations has been successfully used to distinguish the origin of the aerosols [37-40]. Low values of the Single Scattering Albedo (SSA) over Lahore (0.83-0.91) compared to Karachi (0.88-0.97) were observed which indicates that absorbing aerosols are more dominant over Lahore station than Karachi [41].

\section{Study Area}

South Asia covers 3.4\% of the world's geographical area and holds $24 \%$ of the world's population. A most important region of interest is the Indo-Gangetic Plain (IGP), which is adversely affected both at the local and climatic levels in a number of ways. It is also known as Indus-Ganga and the North Indian River Plain, stretching from the Arabian Sea to the Bay of Bengal and from the Himalayan foothills to the Indian peninsula. For Pakistan $\left(33^{\circ} 40^{\prime} \mathrm{N}\right.$ and $\left.73^{\circ} 10^{\prime} \mathrm{E}\right), 24 \%$ of its land and $86 \%$ of its population belongs to the IGP region [42].

Pakistan shares its borders with India on the East, Iran on the West, China in the North and Afghanistan on the north-western side, as depicted in Figure 1 [43,44]. Pakistan is situated in a meteorological zone called the subtropical high region and is largely affected by the movement of both inter-continental and regional air masses coming from the Middle East, Afghanistan, India and the African continent. The surface elevation ranges from the Arabian Sea (in the south) to the world's second highest $(8611 \mathrm{~m})$ peak of K-2 in the north [45].

Seasons in Pakistan are defined on the basis of the occurrence of the monsoon: pre-monsoon (March-May), monsoon (June-September), post-monsoon (October-November) and winter 
(December-February) [46]. The intensity of winter follows with January being the coldest month, followed by December and February [47].

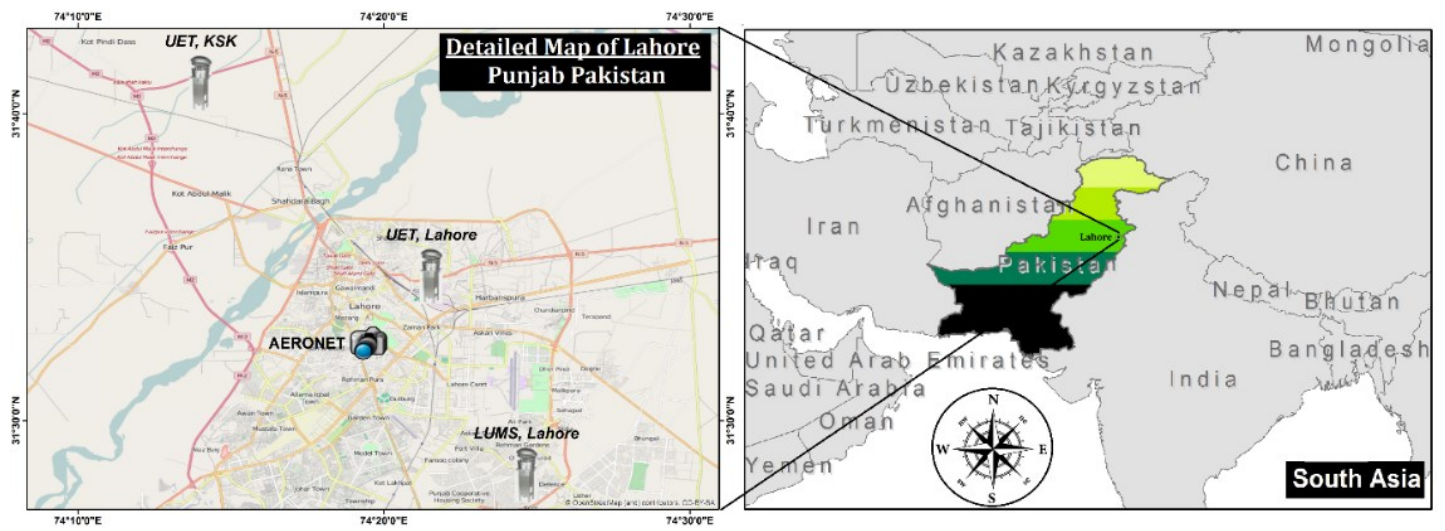

Figure 1. Location of the AERONET station along with three high volume samplers which were installed in Lahore city from December 2014 till February 2015 for continuous monitoring of $\mathrm{PM}_{10}$ concentrations.

One of the major environmental impacts observed over this region is the frequent occurrence of persistent winter fog, particularly during the months of December and January. Towards developing a comprehensive understanding and to study the impacts of persistent winter fog across the IGP, a multi-year and multi-country project was initiated by the International Centre for Integrated Mountain Development (ICIMOD) based in Kathmandu, Nepal. As a part of this initiative, this study had a special focus on Lahore city. It also included ground observations conducted for the 2014-2015 winter period within Lahore city (Figure 1) along with satellite data analysis for the 2012-2015 winter periods.

\section{Materials and Methods}

Two types of datasets are used in this study, namely satellite and ground-based data. Satellite datasets of MODIS, OMI and CALIPSO were used for Aerosol optical depth, Aerosol Types over Land and Vertical Feature Mask (VFM) products, respectively.

The Moderate-resolution Imaging Spectro-radiometer [48] is in orbit on board Terra satellite since 2000 and Aqua satellite since 2002. In this study, we have used the Collection 6 (C6) product which features aerosol optical depth (AOD) and aerosol types over land derived from MODIS-Terra- observed spectral reflectance [49]. Moreover, the AOD MOD04 Level 2 collection 6 uses the Deep Blue algorithm with a spatial resolution of $10 \mathrm{~km}$.

The Dutch-Finnish Ozone Monitoring Instrument (OMI) aboard the Aura satellite launched in July 2004, is a nadir viewing imaging spectrograph. Backscattered solar radiance spectra are measured simultaneously in the wavelength range from $270 \mathrm{~nm}$ to $500 \mathrm{~nm}$. It takes almost one day for global coverage in nadir viewing with a $2600 \mathrm{~km}$ wide swath. Spatial resolution is about $13 \times 24 \mathrm{~km}^{2}$. OMI measures with a spectral resolution of $0.45 \mathrm{~nm}$ in the ultraviolet (UV-2 channel) and $0.63 \mathrm{~nm}$ in the visible [50] wavelength ranges. For the current study, UV Aerosol Index was calculated across a $1^{\circ} \times 1^{\circ}$ resolution.

Launched on 28 April 2006, the Cloud-Aerosol Lidar and Infrared Pathfinder Satellite Observations (CALIPSO) satellite is a part of the "A-train" satellite constellation from NASA in a sun-synchronous orbit. Equipped with the Cloud-Aerosol Lidar with Orthogonal Polarization (CALIOP), this earth observing satellite provides unprecedented high-resolution vertical profiles of both aerosols and clouds [51].

Ground data for Lahore included two types of datasets, namely, the AErosol RObotic NETwork (AERONET) and the High Volume air sampler data. The AERONET Level 2 (cloud screened and other 
quality flags) data was downloaded from AERONET website for the Lahore station. AERONET $500 \mathrm{~nm}$ was used, which was extrapolated to $550 \mathrm{~nm}$ using appropriate conversion formulas given by Equation (1):

$$
\text { AOD aeronet } 550=\text { AOD aeronet } 500\left(\frac{550}{500}\right)^{-\alpha}
$$

where $\alpha$ is the Angstrom exponent for wavelength $500-870 \mathrm{~nm}$ used in this study [52]. While $\mathrm{PM}_{10}$ samplers were installed at three different sites in Lahore city and data was collected on daily basis for winter 2014-2015 only. Figure 1 shows the location of ground observation sites. These sites include:

1. Lahore University of Management Sciences (LUMS), Lahore, Pakistan.

2. University of Engineering and Technology (UET), Lahore campus, Pakistan.

3. University of engineering and Technology (UET), Kala Shah Khaku campus, Pakistan.

Before final analysis, MODIS data was pre-processed by performing geo-referencing and extraction of data over the study area, as indicated in Figure 2.

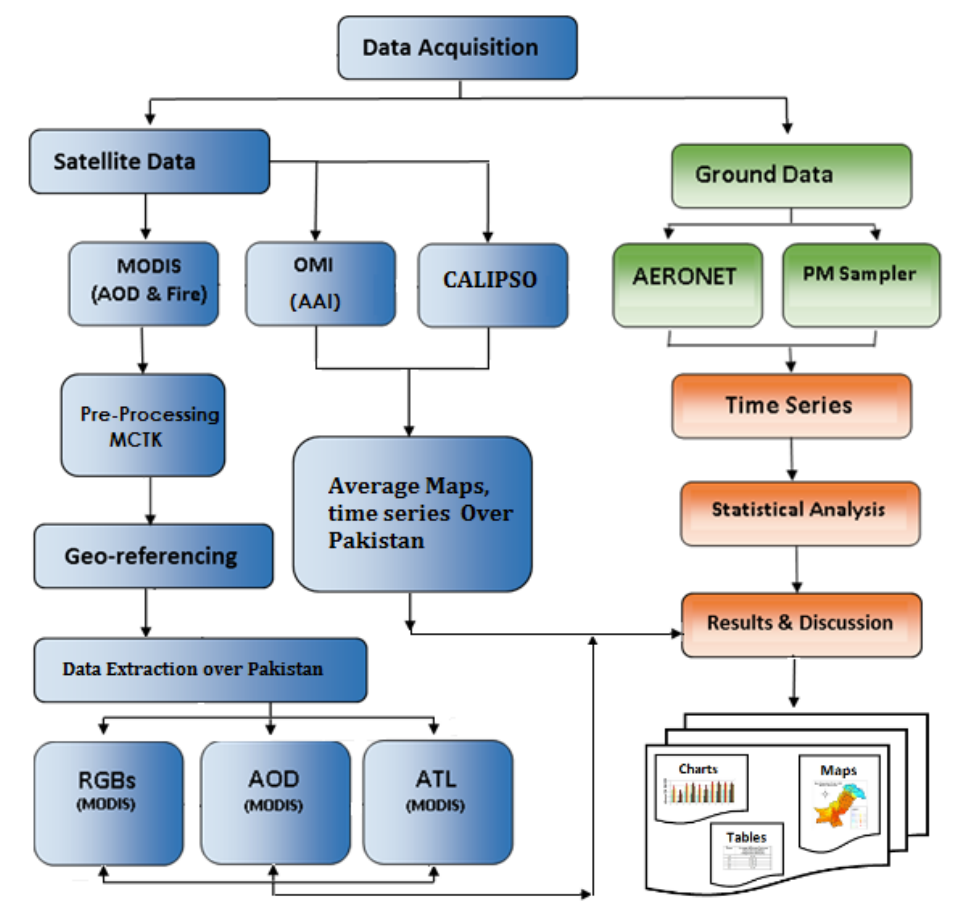

Figure 2. Methodology: flow diagram exhibits the datasets, procedures, and tools used in this study.

From MOD04 data, Aerosol Optical Depth (AOD) and Aerosol Type over Land (ATL) were extracted. MODIS pre-processing was done in ENVI 5 using the MODIS reconversion Tool Kit (MCTK) and average maps were created using IDL scripts. After this analysis, the datasets were georeferenced and mapped by using ArcMap 10.2. Statistical analysis was performed using Microsoft Excel version 2013. The same procedure was applied towards extracting and processing OMI's Absorbing Aerosol Index (AAI) products. Vertical features of the sky using CALIPSO's Level 2 Vertical Feature Mask (VFM) product was extracted using IDL script.

\section{Results and Discussion}

According to the (IPCC, [10]) report, aerosols are recognized as an important factor affecting global climate change and play a key role in processes related to solar and thermal radiative transfer in the atmosphere, water cycle and precipitation processes. During winter seasons in Pakistan, fog becomes very dominant in the months of December, January and February (DJF) [1]. Monthly mean maps of the aerosol optical depth (AOD) retrieved from MODIS observations [53] during the DJF months of each winter (2012-2013, 2013-2014 and 2014-2015) over the study area are shown in Figure 3. 

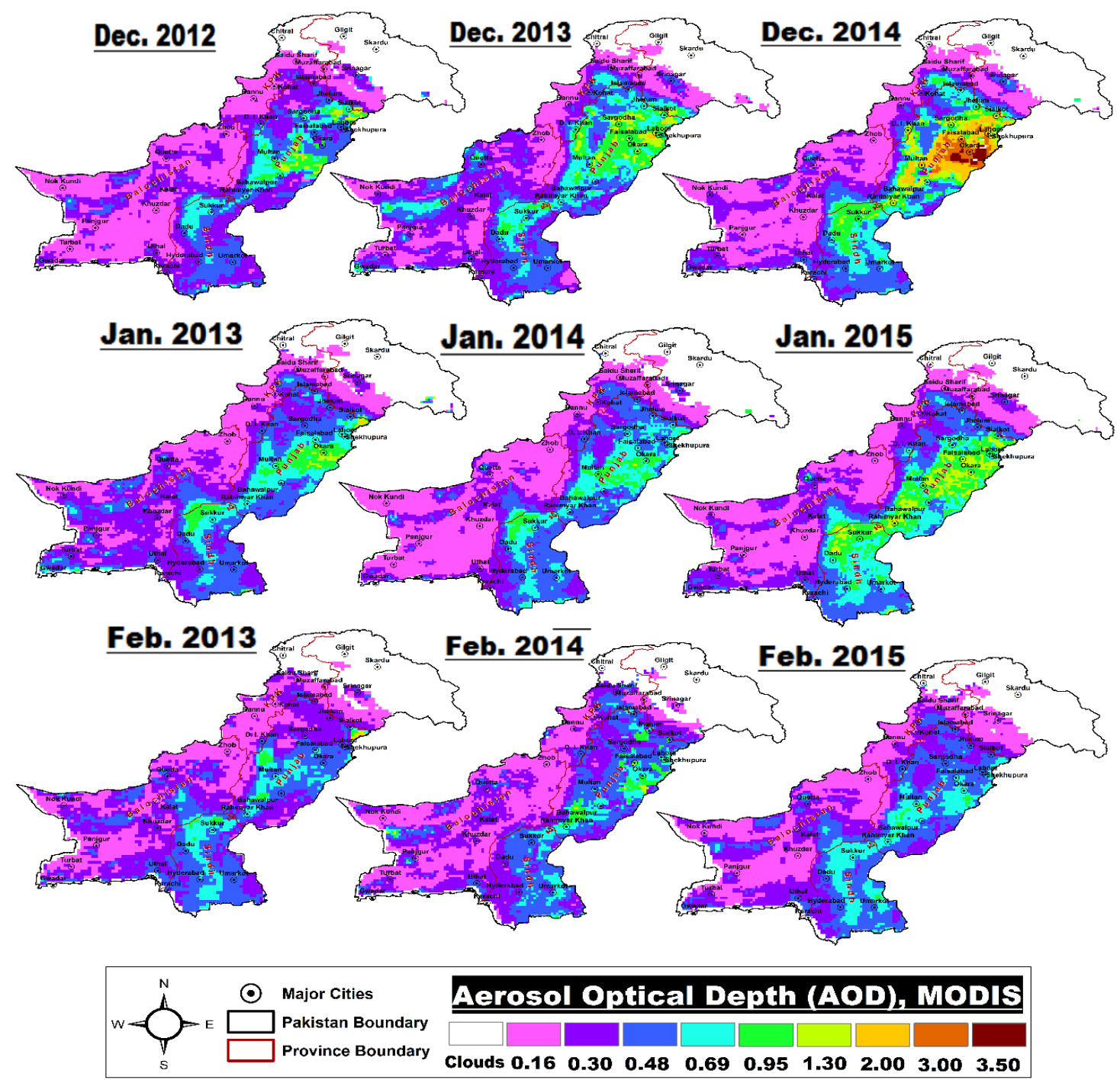

Figure 3. Shows average AOD evolution over Pakistan for each month of the study period. Data is extracted from the MOD04 Level 2 Collection 6 Product. AOD is studied by using deep blue algorithm [49] over Pakistan. Red polygons exhibit the provincial boundaries and the location of the major cities of Pakistan is indicated by small circles in the maps.

Enhanced AOD over the River Indus basin can be clearly identified, as stated by previous studies [34,54]. Its aerosol loading reached a maximum during December, followed by January and February. Continual increasing behaviour in AOD is observed over Pakistan. Especially, the winter of 2014-2015 exhibited anomalous enhanced levels of AOD over Pakistan. Supporting these findings, further, Figure 4 represents results of the average AOD for each winter period selected for the current study (2012-2013, 2013-2014 and 2014-2015). A similar temporal increase in AOD is observed over Pakistan. The overall analysis shows that, as winters are on peak in the months of December and January, this provides favourable conditions for fog formation, as the temperature is low and relative humidity is high. So, the fog intensity and frequency is high over regions along the Indus basin and the major cause is high loads of air pollutants. This area hosts most of the population, industry, dense road networks and vehicular fleet of Pakistan. AOD levels during February exhibit lowered values compared to the December-January months. The overall mean map of February also shows a lower AOD compared to December and January. As stated earlier, the key reason for decreased intensity in February is unfavourable conditions for the fog formation, including lower air pollution levels and comparatively higher air temperature. 


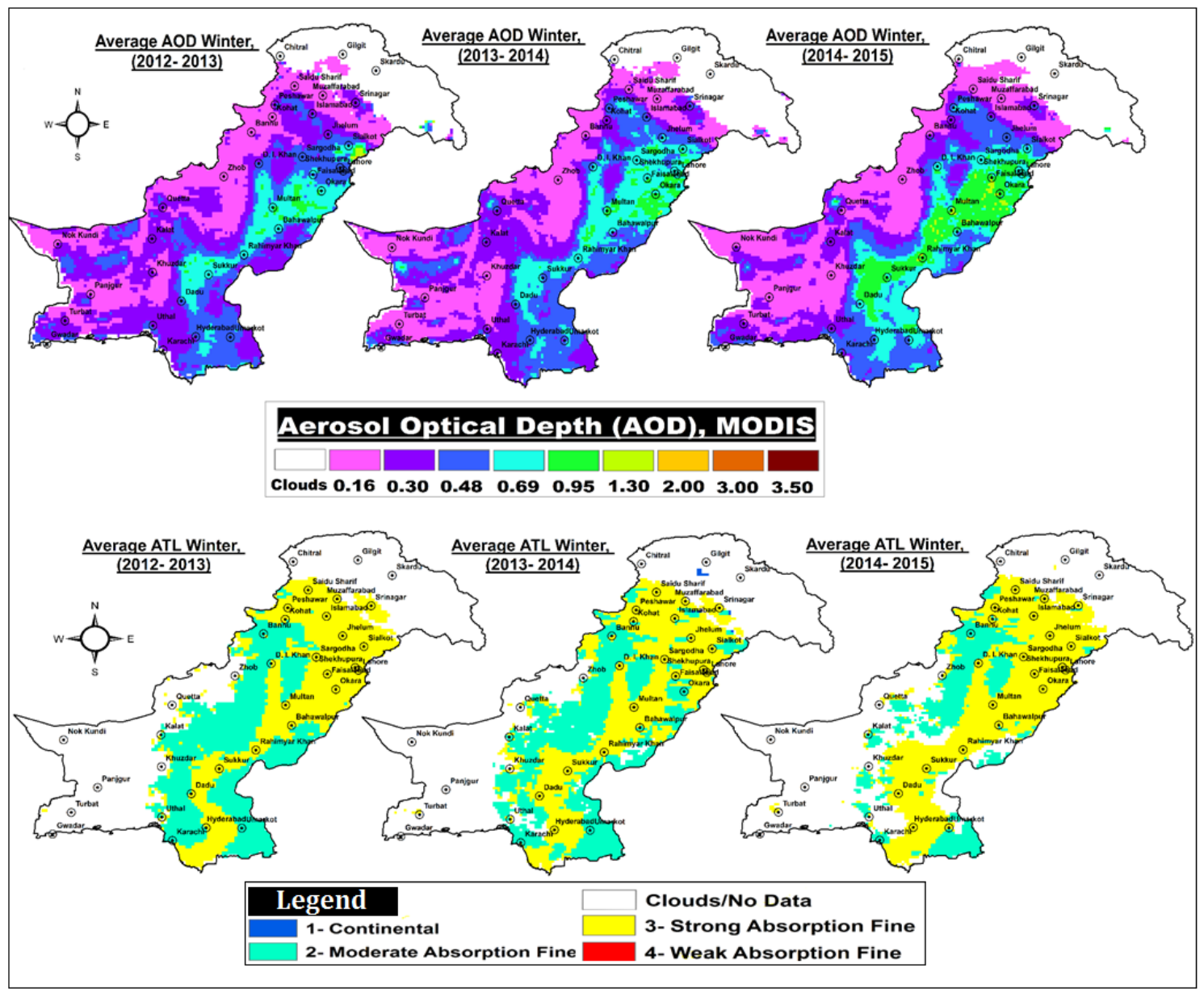

Figure 4. Shows seasonal average for AOD (upper panel) and ATL (lower panel) over Pakistan during winter seasons of 2012-2015. Data is extracted from the MOD04 Level 2 Collection 6 Product [49] over Pakistan. The location of the major cities of Pakistan is indicated by small circles in the maps.

In order to investigate the types of aerosols present over the study area, the MODIS product named MOD04 Level 2 Collection 6 with subset Aerosol Type over land (ATL) was used. MODIS aerosol types were categorized into four types, which include: Continental, Weak, Moderate Absorption Fine and Strong Absorption Fine. According to this classification, the most dominant aerosol types over Pakistan are Strong and Moderate Absorption Fine, as shown in Figure 4 (lower panel-average ATL for each winter period).

To further investigate the types of aerosols, the OMI UV aerosol Index (OMI-UVAI) was also used. It is a residual quantity resulting from the comparison between measured and calculated radiances in the range 330-390 nm, where gas absorption effects are negligible [55]. It is particularly sensitive (even when the aerosols are over clouds) to carbonaceous and mineral aerosols and represents the presence of absorbing aerosols (smoke and dust [56]). For clear sky/Rayleigh scattering conditions, UVAI values are near zero, positive values for absorbing aerosols (smoke, dust), and negative values for non-absorbing aerosols (sea salt, sulfate/nitrates etc.). UVAI calculated for winter months and averaged over all winter periods (2012-2015) is presented in Figure 5b. Results indicate positive UVAI over Pakistan, thus representing the presence of absorbing aerosols. The results are further confirmed by the MODIS ATL product (Figure 5c) averaged over Pakistan during the same time period. It illustrates the presence of both strong (yellow) and moderate (cyan) absorption fine type of aerosols over Pakistan. Aerosol types are also extracted by using OMI-UVAI in combination with CO total columns, as $\mathrm{CO}$ is taken as a good precursor for biomass burning activities [57,58]. The aerosol 
categories here include Smoke (for UVAI $>0.8$ and CO columns $=2.2 \times 10^{18}$ molecules $/ \mathrm{cm}^{2}$ ), Dust (UVAI $>0.8$ for arid and semiarid surface types) and Sulphate (UVAI $<0.8$ ). We find a dominant section of smoke types, as shown in Figure 5d. Additionally, active fire counts were also plotted on both maps that indicated a strong coincidence with smoke types of aerosols. In order to identify the sources of these absorbing aerosols in the study region, these findings are further discussed in details in the next section.
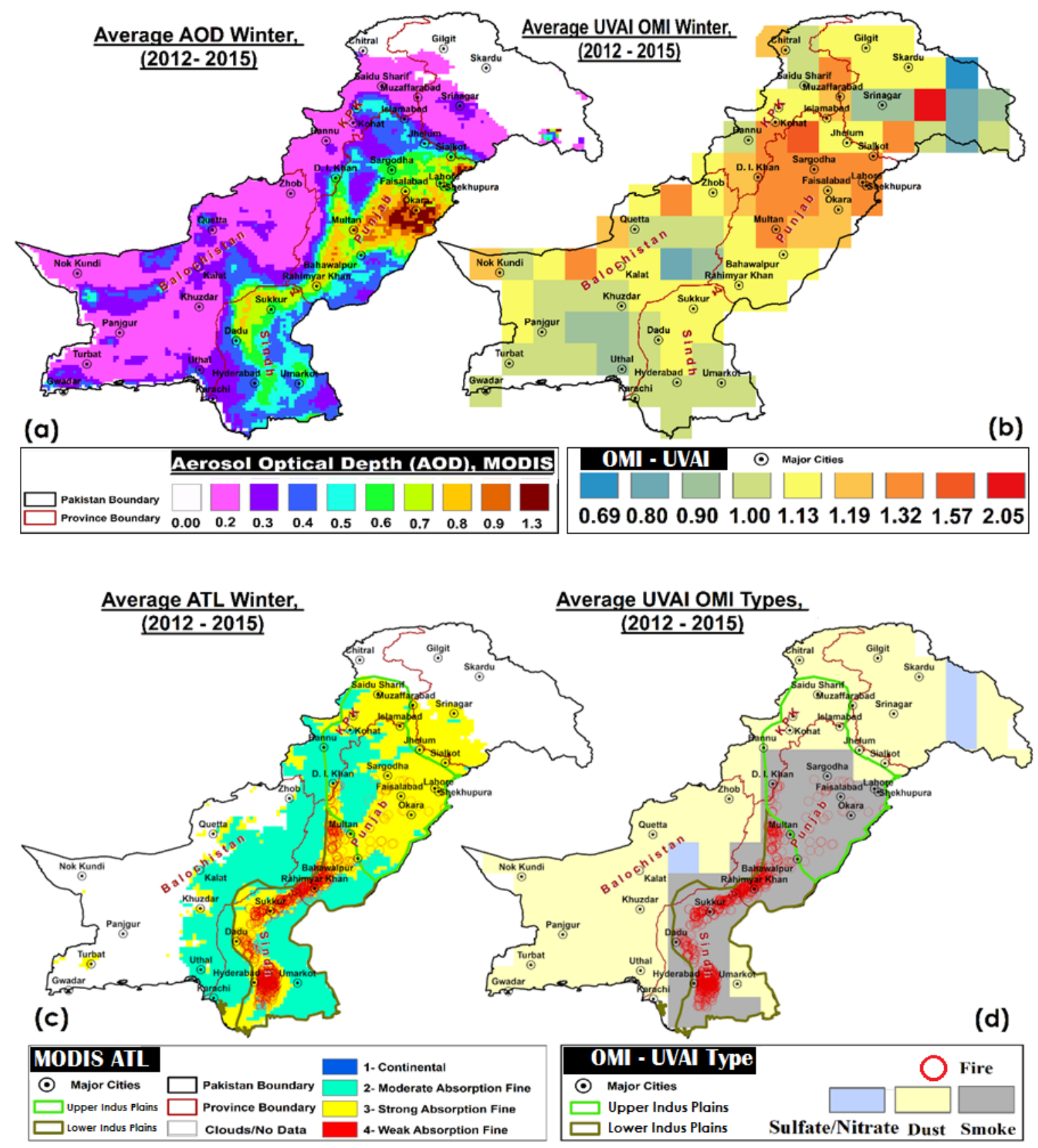

Figure 5. Long-term averages for AOD (a), UV Absorbing Index (b) ATL (c) and type of aerosols (d) derived from UVAI (Torres, 2012). Averages were taken over all winter months (DJF) during the time period of 2012-2015. Data is extracted from MOD04 Level 2 Collection 6 Product [49] over Pakistan. Red polygons exhibit the provincial boundaries and the location of the major cities of Pakistan is indicated by small circles in the maps. The Indus plains were further sub-divided into Upper Indus plains (UIP-light green polygon) and Lower Indus Plains (LIP-dark green polygon). The red circle in the lower panel of figures indicates the fire incidents that occurred during the winter periods of 2012-2015. 


\subsection{Major Sources of Aerosols}

Major sources of aerosols in Pakistan are seasonal biomass-burning smoke and dust storms in addition to industrial and vehicular activities [34,54,59]. Winds are the carrier of these pollutants as cold winds (western disturbances [60]) that arrive from west Asia, northwest India and then change direction to the eastern part, are considered as a major sources of aerosol movement and spread over Bangladesh and the Ganges-Brahmaputra delta [61-63]. Previous studies show that the major causes of fog during the winter season are secondary aerosols and biomass burning, including agriculture fires $[64,65]$. The IGP region is the most fertile region of the subcontinent and agriculture activities are spread over about 400 million hectares of land. In Pakistan, the agriculture sector contributes about 21 percent to GDP and provides livelihood for 60 percent of the population. Most of the agriculture depends on a huge amount of water coming from Hindukush-Karakorum-Himalaya (HKH) glaciers through the river-canal system, ground water pumped through deep wells and heavy precipitation, especially during the monsoon season. Groundwater use is about 35 percent for agriculture and 42 percent of the area in the Indus basin has a ground water table less than $3 \mathrm{~m}$ deep [66]. Therefore, soil moisture content is largely available for extensive agriculture practices. According to [67], winds coming from India provide favourable conditions for dense fog formation over the IGP, with low temperature and high relative humidity conditions which also enhance aerosol radiative forcing.

Farmers in Pakistan light their fields to make them ready for the next crop, as post-harvest fires are an easy and cost-effective way to get rid of crop residue, weeds, and pests and to get nutrients for the next crop. Large numbers of agriculture fires are observed across the Indus plains during crop harvesting seasons. Mainly, fires are intense during the months of April-May for clearing wheat residue and during October-November for rice paddies [54,59], followed by January-February months for the sugarcane crop. Agricultural fires emit aerosol particles, greenhouse gases, and various trace gases into the atmosphere [68]. Active fire data plotted as red circles in Figure 5c,d over the study area are taken from MODIS active fire data (MCD14DL) downloaded from the website [69]. It can be seen that regions with extensive vegetation fires are spread along the Indus plains in Pakistan consistent with enhanced levels of AOD (Figure 5a). The agriculture plains of the Sindh and Punjab provinces along the River Indus have the largest fire density. Similar patterns are observed in AOD and aerosol types retrieved from both MODIS (Figure 5c-aerosol type over land) and OMI (Figure 5d-smoke). The analysis presented in Figure 5 revealed that absorbing aerosols are predominant and originated from fire activities (both agriculture and biomass burning) in addition to vehicular and industrial emissions. Especially, during the winter season use of biofuel (char wood, dung cake, and coal) is increased for space heating and cooking due to power and natural gas outages in Pakistan. It results in enhanced emission of aerosols, smoke, black carbon and other gases such as $\mathrm{NO}_{2}, \mathrm{SO}_{2}$ and $\mathrm{CO}[13,68,70]$. Recently, several studies used satellite monitoring of various trace gases such as $\mathrm{SO}_{2}, \mathrm{NO}_{2}$ and $\mathrm{CO}$ in order to identify the source region of aerosols, as these originate from the same sources as these tiny particles [71-74]. In order to investigate such a relationship between AOD and aerosol precursor gases, the Indus plains were divided into two different regions: Upper Indus Plains (UIP-light green polygons in Figure 5c, d) and Lower Indus Plains (LIP-dark green polygons in Figure 5c, d). UIP includes the parts of Khyber Pakhtunkhwa (KPK), northern and central Punjab provinces while LIP consists of regions of southern Punjab and Sindh province (excluding Karachi). Both regions have different dynamics with respect to agriculture fires and industrial activities. The Upper Indus plains host most of the populated regions with extensive vehicular and industrial emissions. Various studies have shown increasing trends in $\mathrm{NO}_{2}$ [12], $\mathrm{SO}_{2}$ [75] and formaldehyde [59], mainly caused by vehicular, industrial and biomass burning activities. In contrast, the southern plains host few industries, less population but extensive agriculture activities and fires activities (Figure 5). Correlation between AOD and aerosol precursor gases over both regions is presented in Table 1 during the winter periods of 2012-2015. It can be clearly identified that AOD in the UIP region is contributed to by $\mathrm{NO}_{2}$ and $\mathrm{SO}_{2}$ emission sources (precursor of nitrates and sulfate aerosols) while the LIP region is dominated by $\mathrm{CO}$ emissions-a good tracer of fire activities and for the presence of both organic and elemental carbon. Our findings about major aerosol sources are in agreement with source apportionment of the particulate 
matter presented in previous studies [37-41]. High aerosol levels are influencing climate and the hydrological cycle due to dimming and atmospheric warming [76,77]. During winter, 50-70 $\mathrm{WM}^{-2}$ of atmospheric heating is observed because of a high level of black carbon [64]. Many recent studies confirm that the accelerated snow melt in the Himalayas is due to deposition of $\mathrm{BC}$ over snow sheets and has caused a reduction in surface albedo during the pre-monsoon [78-80]. Therefore, abatement of agriculture fires and open solid waste burning can result in a substantial decrease in dense fog formation in the study region. Similarly, the outcome of this study can be effectively used to raise awareness to stop the usage of dirty fuel (old rubber tires, solid waste, low standard furnace oil etc.) in factories and brick kilns in Pakistan. These sources trigger the aerosol load which results in the frequent occurrence of dense fog/smog and consequently results in casualties (road accidents) and economic losses in Pakistan, besides increasing health impacts.

Table 1. Correlation between AOD and different trace gases during the time period of winter 2012-2015.

\begin{tabular}{ccccc}
\hline Region & Provinces & $\mathbf{C O}$ & $\mathbf{N O}_{\mathbf{2}}$ & $\mathbf{S O}_{2}$ \\
\hline Upper Indus Plains (UIP) & KPK, Northern and Central Punjab & -0.07 & 0.38 & 0.47 \\
Lower Indus Plains (LIP) & Southern Punjab and Sindh & 0.6 & -0.37 & 0.09 \\
Indus Plains & KPK, Punjab, Sindh & 0.37 & 0.11 & 0.45 \\
\hline
\end{tabular}

\subsection{Persistent Winter Fog over Lahore City}

Lahore is the second largest metropolitan city of Pakistan and is the 16th most populated city in the world. As shown earlier in the overall view of Pakistan, this study exhibited a temporal increase in AOD across Pakistan, including Lahore city. A higher value of AOD was observed in December than that in February in Lahore city, as February is warmer than December (see Table 2). However, the overall increase in AOD is observed over Lahore city. In January 2014, a declining tendency is observed for AOD for Lahore city. The discrepancy was apparently caused as the study region experienced warmer temperatures in January 2014 (temp. anomaly $=-0.07^{\circ} \mathrm{C}$ ) as compared to January months during the year 2013 (temp. anomaly $=-0.9^{\circ} \mathrm{C}$ ) and 2015 (temp. anomaly $=-0.49^{\circ} \mathrm{C}$ ). Temperature anomaly was calculated by using CAMS monthly gridded surface air temperature [81] with respect to the base years of 1970-2000. As warmer temperature leads to unstable atmospheric conditions, rapid movement of air masses might have dispersed the aerosols over larger areas. Consequently, it resulted in less accumulation of aerosols over the study region. On the other hand, warmer temperature also results in a relatively smaller number of fog incidents and, thus, reduced aerosol emissions caused by space heating and other activities. This can be clearly seen from Figure $6 b$, which depicts a significantly smaller number of overall fog incidents during the month of January 2014 as compared to January 2013 and 2015.

Figure 6a displays the temporal evolution of daily mean AOD over Lahore city for the past 3 winters and exhibited a relative increase of $61 \%$ with respect to the winter of 2012-2013. An increase in anthropogenic aerosol over South Asia is also evident from previous studies [82-85]. Various studies reported the increase in aerosol load [34] and precursor gases [12,75] over Lahore city. Figure 6b shows the trend in fog incidents/days observed in Lahore city during all winters. Fog was categorized into three different types on the basis of visibility (i) dense fog-when visibility is less than $200 \mathrm{~m}$; (ii) moderate fog-when visibility is less than $500 \mathrm{~m}$; and (iii) shallow fog-when visibility is less than $1000 \mathrm{~m}$ [86]. Visibility data was acquired from the following online source [87] and it uses data from the national weather service of the respective country. Fog incidents were also verified with MODIS true colour RGBs and daily news bulletins in both electronic and print media. A continual increase in dense fog incidents was observed for all winter periods. A maximum number of dense fog incidents were observed during the winter of 2014-2015 followed by 2013-2014 and 2012-2013. It is worth mentioning that February 2015 experienced anomalous incidents of moderate and dense fogs. It shows that the span of winter fog was extended during the winter season of 2014-2015. AERONET data was used to validate MODIS satellite-based observations, as shown in Figure 6(c). It exhibited an overall good agreement between daily satellite and ground-based AOD observation for all winters over Lahore city. 
This comparison only includes the dates on which both MODIS and AERONET data were available and AERONET data was extrapolated to $550 \mathrm{~nm}$ wavelength [52]. A significant correlation of $86 \%$ is observed in Figure $6 \mathrm{~d}$ for the complete study period. Similarly, good correlation of $r=0.73,0.78$ and 0.84 was observed for each winter period of 2012-2013, 2013-2014 and 2014-2015, respectively.

Table 2. Temporal evolution of AOD over Lahore City retrieved from MODIS observations.

\begin{tabular}{ccccc}
\hline Month & Winter (2012-2013) & Winter (2013-2014) & Winter (2014-2015) & Average \\
\hline December & 0.37 & 0.90 & 1.08 & $0.67 \pm 0.15$ \\
January & 0.54 & 0.43 & 0.84 & $0.62 \pm 0.09$ \\
February & 0.39 & 0.64 & 0.63 & $0.56 \pm 0.06$ \\
Average & 0.43 & 0.57 & 0.84 & $0.62 \pm 0.09$ \\
\hline
\end{tabular}
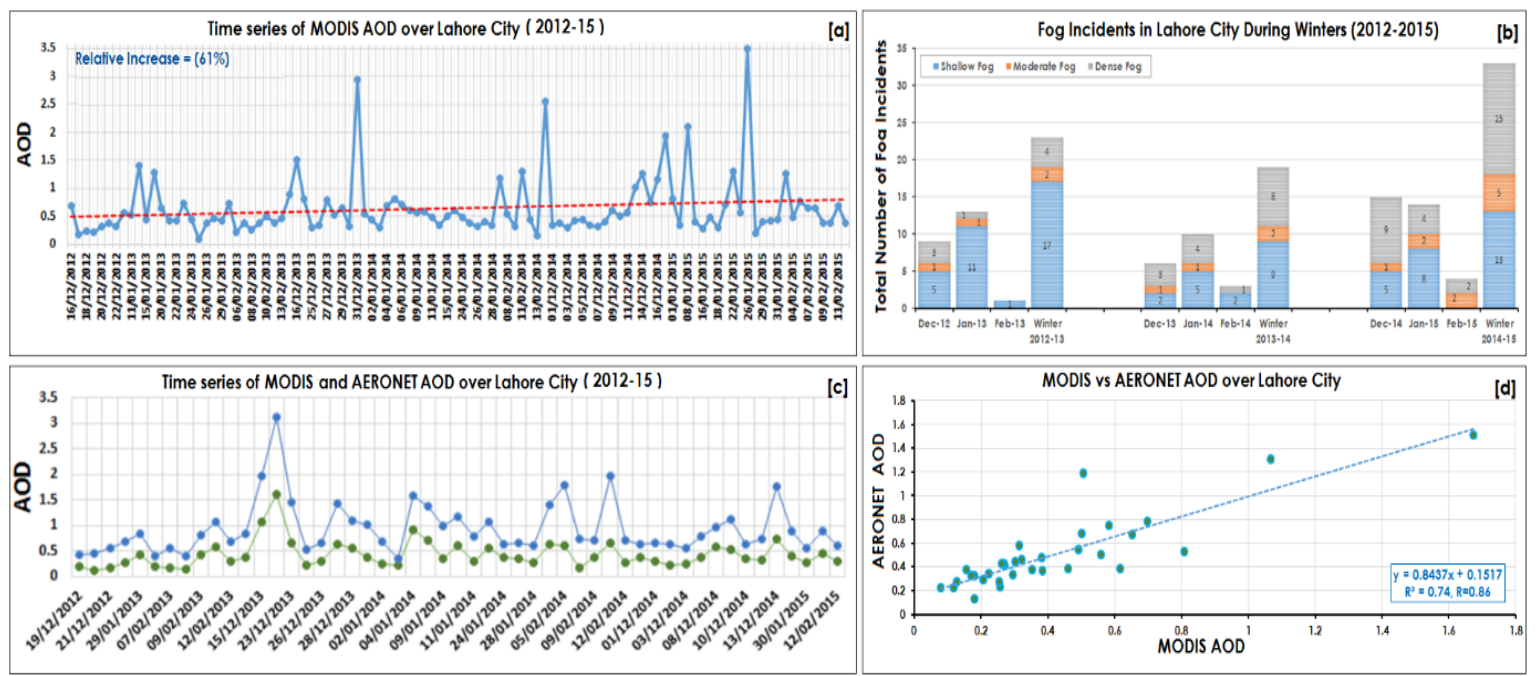

Figure 6. (a) Time series of daily MODIS-derived AOD over Lahore city during all winters (2012-2015); (b) Total number of fog incidents (dense fog = grey colour, moderate fog = orange colour, shallow fog $=$ blue colour) in Lahore city during respective winter seasons and each month as well; (c) Comparison of daily AOD between MODIS and AERONET observations for all winters; (d) Correlation measured between MODIS and AERONET observations for Lahore city. Data is extracted from the MOD04 Level 2 Collection 6 Product by using deep blue algorithm [49].

\subsection{Case Study-Winter 2014-2015}

This study also had a special focus on the 2014-2015 winter in terms of field data collection for winter months in Lahore-one of the most polluted city in Pakistan [11,41]. High volume samplers were installed for continuous monitoring of $\mathrm{PM}_{10}$ concentrations at three different locations within Lahore city. Figure 7 displays the measured $\mathrm{PM}_{10}$ concentration in Lahore city at three different sites: University of Engineering and Technology (UET), Kala Shah Khaku (KSK) campus, University of Engineering and Technology (UET), Lahore campus and Lahore University of Management Science (LUMS), Lahore, Pakistan. $\mathrm{PM}_{10}$ concentration was measured for $24 \mathrm{~h}$ duration by using High Volume $\mathrm{PM}_{10}$ samplers (Wedding and Associates Inc., Fort Collins, CO, USA) during the time period of January 2015-February 2015. Quartz filters (QMA by Whatman International Ltd., Maidstone, England), because of their high collection efficiency as well as their ability to withstand high temperatures, were used to collect the samples on a daily basis. Filters were pre-processed at $120^{\circ} \mathrm{C}$ and weighed before and after the filter was removed from the sampler. The red line in the graph represents the National Environmental Quality Standards (NEQS) of $150 \mu \mathrm{g} / \mathrm{m}^{3}$ for 24 hours average concentrations of $\mathrm{PM}_{10}$ defined by the Pakistan Environmental Protection Agency (Pak-EPA, [88]).It is observed that $\mathrm{PM}_{10}$ levels at all monitoring sites exceeded the Pak-NEQs level on most of the occasions. Data gaps were caused by both the frequent power outages in Pakistan and malfunctioning of the instruments. Especially, the number of samples collected at both campuses of UET are less because these sites 
did not have a power backup system like the one available at the LUMS site. Correlation between mass concentrations of $\mathrm{PM}_{10}$ and MODIS-retrieved AOD is presented in Figure $7 \mathrm{~d}$. Limited data was available as all monitoring sites in Lahore city were not having the filter samples on a daily basis because of aforementioned constraints. So, the correlation was calculated for mean $\mathrm{PM}_{10}$ mass concentration from all sites. Additionally, MODIS AOD was also not available on certain days because of cloud cover. The observed correlation of $r=0.67$ is quite good and is in agreement with the range stated in previous studies [89-92] for similar kinds of comparison. Furthermore, the correlation depends on various factors such as seasonal variation, meteorological parameters, spatial resolution of the satellite pixel (10 km in this case) and aloft aerosol layer [89-92].

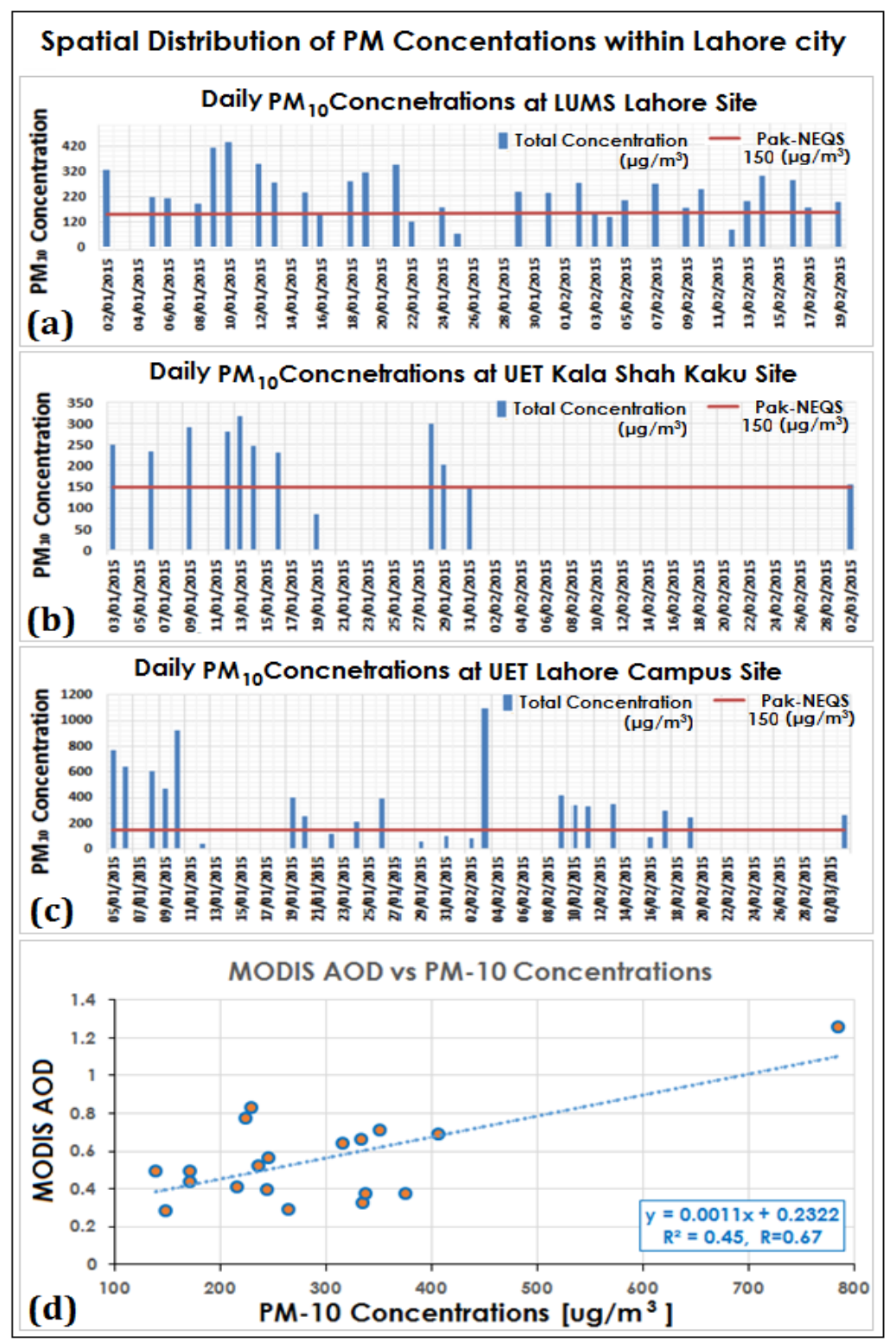

Figure 7. Shows spatial distribution of $\mathrm{PM}_{10}$ mass concentrations $\left(\mu \mathrm{g} / \mathrm{m}^{3}\right)$ measured at three different sites in Lahore city: (a) Lahore University of Management Sciences; (b) University of Engineering and Technology (UET), Kala Shah Khaku (KSK) campus; (c) University of Engineering and Technology (UET), Lahore campus, during the winter months. The red line in each graph represents the Pak-NEQS for $\mathrm{PM}_{10}$ in ambient conditions; (d) shows the correlation between MODIS-retrieved AOD and average $\mathrm{PM}_{10}$ concentration at all monitoring stations. Only days were selected when both MODIS and any of the three monitoring sites had data. 


\subsection{HYSPLIT Back Trajectory Analysis}

Wind direction and wind speed can have a strong influence on observations of local emission sources. For such observations, the study of back trajectories of the observed air masses might be interesting. Some instructive case studies were found during this study, where high aerosol loads were observed and back trajectory analyses were performed. Figure 8 presents the true colour images (RGB) for fog and clouds, MODIS AOD and air masses movements explored by back trajectories analysis on respective days. In RGB, white colour represents clouds and snow along with the greyish tone for fog distribution over the selected scenes. High AOD levels were also observed over the regions classified as fog on both days of 13 December 2013, and 23 January 2015. To study the reason for these high AOD loadings, the Hybrid Single Particle Lagrangian Integrated Trajectory Model-4 [93-95] was used. The model was run for reanalysis of back trajectories for $96 \mathrm{~h}$, at 50, 200 and $500 \mathrm{~m}$ above ground level by selecting a location in Lahore city (black star in all maps). It was found that air masses calculated at three different heights were coming from India. Air masses propagated over the densely populated and industrial regions of Uttarakhand, western parts of Uttar Pradesh, Haryana, New Delhi and the Punjab before entering Pakistan. Almost similar transport patterns were observed for both days, which indicates transboundary air pollution as an important factor contributing to high aerosol loading observed over the city of Lahore, Pakistan $[39,40]$.
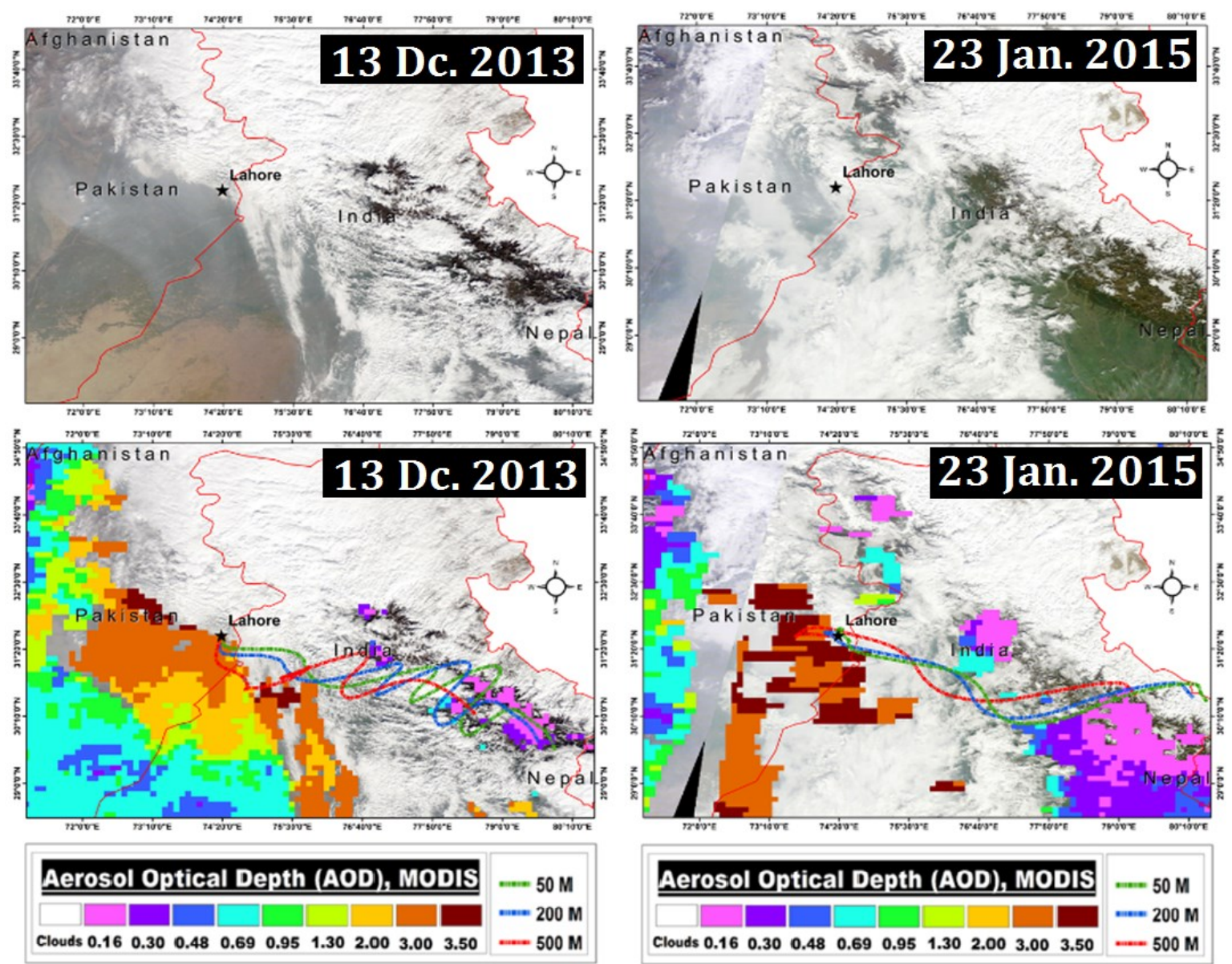

Figure 8. Shows spatial distribution of AOD overlaid on RGB image obtained from MODIS observations on 13 December 2013 (in left panel) and on 23 January 2015 (in right panel). Back trajectory analyses were also performed on both occasions for $96 \mathrm{~h}$ back in time at three different altitudes of 50 (green), 200 (blue) and 500 (red) $\mathrm{m}$ above ground level. 
Moreover, CALIPSO overpasses over the Pakistan were used to further identify the aerosol layer, types and clouds by using the vertical feature mask on both days. Results are shown in Figure 9a,b. Both maps indicate low-lying aerosol layers (orange colour) as a dominant feature on both occasions of 13 December 2013 and 23 January 2015.
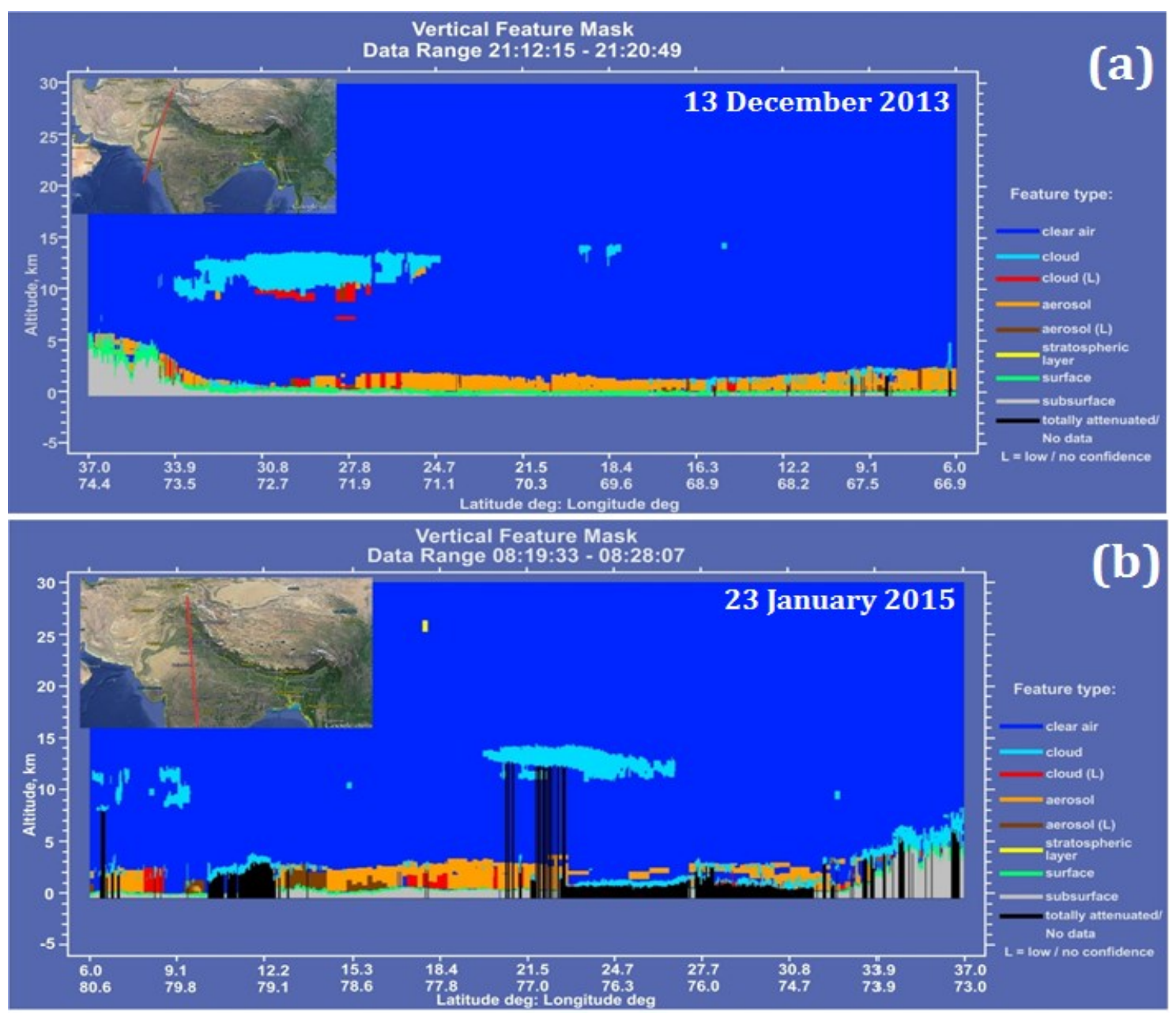

Figure 9. Shows spatial distribution of aerosol, clouds along the overpass of CALIPSO Satellite by using the vertical feature mask: (a) on the night of 13 December 2013, with the location of the overpass (red line) provided in the inset image; (b) on 23 January 2015, with the location of the overpass (red line) provided in the inset image. Aerosol in both cases is represented by orange colour, while clouds are depicted in cyan colour.

\section{Conclusions}

Our findings show that during the 2012-2015 winter periods in Pakistan, December and January months experience more fog incidents and relatively higher AOD. As the winter season goes on, the intensity of foggy weather decreases with the aerosol load decreasing as well, which is supported by the observations. The lowest mean AOD was found during December 2012 and highest AOD in December 2014 with an overall increasing behaviour in AOD observed over Pakistan. The continual increase in the frequency of dense fog occurrences is also observed. Anomalous incidents of dense and moderated fogs were identified during February 2015. It shows that the span of winter fog was extended during the winter season of 2014-2015. The dominant type of aerosol is medium and strong absorption fine retrieved from the MODIS ATL product, which was further confirmed by OMI UVAI data (categorized as smoke and dust). MODIS AOD, compared well with the AERONET AOD in Lahore city and exhibited a significant correlation of $r=0.86$. Active fire locations from MODIS were 
strongly co-located with aerosol types of smoke. It revealed that agriculture fires and biomass burning are predominant sources of aerosols and its precursor gases in the Indus delta, in addition to increased used of biofuel and industrial activities. Reanalysis Back trajectories have shown that increasing AOD over Pakistan, is also caused by transboundary pollution on selected days. It was further supported by the CALIPSO overpasses over the Pakistan region and indicated the presence of low-lying aerosol layers, in addition to clouds. Mass concentrations of $\mathrm{PM}_{10}$ measured at all sampling sites within Lahore city were found to be higher than Pakistan's NEQS Level for $\mathrm{PM}_{10}$ on most occasions.

Acknowledgments: Authors gratefully acknowledge the CALIPSO, MODIS, OMI teams for providing the Level-2 data products. We also acknowledge Data of Firm active fire from NASA (National Aeronautics and Space Administration). Our special gratitude goes to ICIMOD-Nepal and NUST for providing partial financial support from postgraduate R\&D fund to conduct this study and our collaborating partner from LUMS, UET Lahore, and Kala Shah Kaku Campuses.

Author Contributions: Fahim Khokhar and Farrukh Chishtie conceived and designed the experiments; Naila Yasmin analyzed results over all Pakistan and Imran Shahid was the part of the team who performed $\mathrm{PM}_{10}$ sampling in Lahore City. Fahim Khokhar wrote the paper and supervised this study.

Conflicts of Interest: The authors declare no conflict of interest.

\section{Abbreviations}

The following abbreviations are used in this manuscript:

$\begin{array}{ll}\text { IGP } & \text { Indo-Gangetic Plains } \\ \mathrm{km}^{2} & \text { Square Kilometer } \\ \mathrm{AOD} & \text { Aerosol optical depth } \\ \mathrm{nm} & \text { Nanometer } \\ \text { UV-Vis-NIR-SWIR } & \text { Ultraviolet, Visible, Near Infrared, Short Wavelength Infrared } \\ \text { MODIS } & \text { Moderate Resolution Imaging Spectroradiometer } \\ \text { OMI } & \text { Ozone monitoring instrument } \\ \text { CALIPSO } & \text { Cloud-Aerosol Lidar and Infrared Pathfinder Satellite Observations } \\ \text { AERONET } & \text { AErosol RObotic NETwork }\end{array}$

\section{References}

1. Syed, F.S.; Körnich, H.; Tjernström, M. On the fog variability over South Asia. Clim. Dyn. 2012, 39, $2993-3005$. [CrossRef]

2. Gultepe, I.; Tardif, R.; Michaelides, S.; Cermak, J.; Bott, A.; Bendix, J.; Müller, M.; Pagowski, M.; Hansen, B.; Ellrod, G. Fog research: A review of past achievements and future perspectives. Pure Appl. Geophys. 2007, 164, 1121-1159. [CrossRef]

3. Dejmal, K.; Repal, V. Forecasting the Formation of Radiation Fog. Available online: http://www.wseas.us / e-library/conferences/2010/Taipei/FH/FH-44.pdf (accessed on 29 February 2016).

4. Muslehuddin, M.; Mir, H.; Faisal, N. Recent occurrence of fog over pakistan (1997 to 2000). Pak. J. Meteorol. 2004, 1, 3-18.

5. Bushahab, A.; Al Suwaidi, A.; Ghedira, H.; Mubarak, K. Fog forecasting, detection and monitoring in the Uae using seviri-msg data. In Proceedings of the 2009 IEEE International Geoscience and Remote Sensing Symposium, Cape Town, South Africa, 12-17 July 2009; pp. 535-538.

6. Ramanathan, V.; Crutzen, P.J.; Kiehl, J.T.; Rosenfeld, D. Aerosols, climate, and the hydrological cycle. Science 2001, 294, 2119-2124. [CrossRef] [PubMed]

7. Charlson, R.J.; Schwartz, S.E.; Hales, J.M.; Cess, R.D.; Coakley, J.A.; Hansen, J.E.; Hofmann, D.J. Climate forcing by anthropogenic aerosols. Science 1992, 255, 423-430. [CrossRef] [PubMed]

8. Kosmopoulos, P.G.; Kaskaoutis, D.G.; Nastos, P.T.; Kambezidis, H.D. Seasonal variation of columnar aerosol optical properties over athens, greece, based on modis data. Remote Sens. Environ. 2008, 112, 2354-2366. [CrossRef]

9. Lohmann, U.; Feichter, J. Global indirect aerosol effects: A review. Atmos. Chem. Phys. 2005, 5, 715-737. [CrossRef]

10. Solomon, S. IPCC (2007): Climate Change the Physical Science Basis. In Proceedings of the AGU Fall Meeting Abstracts, San Francisco, CA, USA, 10-14 December 2007. 
11. Shabbir, Y.; Khokhar, M.F.; Shaiganfar, R.; Wagner, T. Spatial variance and assessment of nitrogen dioxide pollution in major cities of pakistan along n5-highway. J. Environ. Sci. 2015. [CrossRef] [PubMed]

12. Khokhar, M.F.; Yasmin, N.; Fatima, N.; Beirle, S.; Wagner, T. Detection of trends and seasonal variation in tropospheric nitrogen dioxide over Pakistan. Aerosol Air Qual. Res. 2015, 15, 2508-2524. [CrossRef]

13. Seinfeld, J.; Pandis, S. Atmospheric Chemistry and Physics, a Wiley-Inter Science Publication; John Wiley \& Sons Inc.: New York, NY, USA, 2006.

14. Brooks, S.D.; Gonzales, M.; Farias, R. Using surface tension measurements to understand how pollution can influence cloud formation, fog, and precipitation. J. Chem. Educ. 2009. [CrossRef]

15. Mohan, M.; Payra, S. Influence of aerosol spectrum and air pollutants on fog formation in urban environment of megacity Delhi, India. Environ. Monit. Assess. 2009, 151, 265-277. [CrossRef] [PubMed]

16. Chen, L.-W.A.; Doddridge, B.G.; Dickerson, R.R.; Chow, J.C.; Henry, R.C. Origins of fine aerosol mass in the baltimore-Washington corridor: Implications from observation, factor analysis, and ensemble air parcel back trajectories. Atmos. Environ. 2002, 36, 4541-4554. [CrossRef]

17. Andreae, M.O. Chapter 10 climatic effects of changing atmospheric aerosol levels. In World Survey of Climatology; Henderson-sellers, A., Ed.; Elsevier: Amsterdam, The Netherlands, 1995; Volume 16, pp. 347-398.

18. Rosenfeld, D.; Lensky, I.M. Satellite-based insights into precipitation formation processes in continental and maritime convective clouds. Bull. Am. Meteorol. Soc. 1998, 79, 2457-2476. [CrossRef]

19. Twomey, S. The influence of pollution on the shortwave albedo of clouds. J. Atmos. Sci. 1977, 34, 1149-1152. [CrossRef]

20. D'Almeida, G.A.; Koepke, P.; Shettle, E.P. Atmospheric Aerosols: Global Climatology and Radiative Characteristics; A Deepak Publishing: Hampton, VA, USA, 1991.

21. Kaskaoutis, D.G.; Kambezidis, H.D.; Hatzianastassiou, N.; Kosmopoulos, P.G.; Badarinath, K.V.S. Aerosol climatology: On the discrimination of aerosol types over four aeronet sites. Atmos. Chem. Phys. Discuss. 2007, 7, 6357-6411. [CrossRef]

22. Menon, S.; Hansen, J.; Nazarenko, L.; Luo, Y. Climate effects of black carbon aerosols in China and India. Science 2002, 297, 2250-2253. [CrossRef] [PubMed]

23. Sarkar, S.; Chokngamwong, R.; Cervone, G.; Singh, R.P.; Kafatos, M. Variability of aerosol optical depth and aerosol forcing over India. Adv. Space Res. 2006, 37, 2153-2159. [CrossRef]

24. Otto, S.; de Reus, M.; Trautmann, T.; Thomas, A.; Wendisch, M.; Borrmann, S. Atmospheric radiative effects of an in situ measured saharan dust plume and the role of large particles. Atmos. Chem. Phys. 2007, 7, 4887-4903. [CrossRef]

25. Haywood, J.M.; Francis, P.N.; Glew, M.D.; Taylor, J.P. Optical properties and direct radiative effect of saharan dust: A case study of two saharan dust outbreaks using aircraft data. J. Geophys. Res. Atmos. 2001, 106, 18417-18430. [CrossRef]

26. Smart, J.C.R.; Hicks, K.; Morrissey, T.; Heinemeyer, A.; Sutton, M.A.; Ashmore, M. Applying the ecosystem service concept to air quality management in the UK: A case study for ammonia. Environmetrics 2011, 22, 649-661. [CrossRef]

27. Tripathi, S.N.; Dey, S.; Chandel, A.; Srivastava, S.; Singh, R.P.; Holben, B.N. Comparison of modis and aeronet derived aerosol optical depth over the Ganga Basin, India. Ann. Geophys. 2005, 23, 1093-1101. [CrossRef]

28. Penner, J.E.; Dickinson, R.E.; O'Neill, C.A. Effects of aerosol from biomass burning on the global radiation budget. Science 1992, 256, 1432-1434. [CrossRef] [PubMed]

29. Yoon, J.; Burrows, J.; Vountas, M.; von Hoyningen-Huene, W.; Chang, D.; Richter, A.; Hilboll, A. Changes in atmospheric aerosol loading retrieved from space-based measurements during the past decade. Atmos. Chem. Phys. 2014, 14, 6881-6902. [CrossRef]

30. Kaufman, Y.J.; Tanré, D.; Boucher, O. A satellite view of aerosols in the climate system. Nature 2002, 419, 215-223. [CrossRef] [PubMed]

31. Mao, K.; Ma, Y.; Xia, L.; Chen, W.Y.; Shen, X.; He, T.; Xu, T. Global aerosol change in the last decade: An analysis based on modis data. Atmos. Environ. 2014, 94, 680-686. [CrossRef]

32. Mishchenko, M.I.; Geogdzhayev, I.V.; Rossow, W.B.; Cairns, B.; Carlson, B.E.; Lacis, A.A.; Liu, L.; Travis, L.D. Long-term satellite record reveals likely recent aerosol trend. Science 2007, 315, 1543-1543. [CrossRef] [PubMed]

33. Mishchenko, M.I.; Geogdzhayev, I.V. Satellite remote sensing reveals regional tropospheric aerosol trends. Opt. Express 2007, 15, 7423-7438. [CrossRef] [PubMed] 
34. Alam, K.; Qureshi, S.; Blaschke, T. Monitoring spatio-temporal aerosol patterns over Pakistan based on modis, toms and misr satellite data and a hysplit model. Atmos. Environ. 2011, 45, 4641-4651. [CrossRef]

35. Kaufman, Y.J.; Koren, I.; Remer, L.A.; Rosenfeld, D.; Rudich, Y. The effect of smoke, dust, and pollution aerosol on shallow cloud development over the Atlantic Ocean. Proc. Natl Acad. Sci. USA 2005, 102, 11207-11212. [CrossRef] [PubMed]

36. Nakajima, T.; Higurashi, A.; Kawamoto, K.; Penner, J.E. A possible correlation between satellite-derived cloud and aerosol microphysical parameters. Geophys. Res. Lett. 2001, 28, 1171-1174. [CrossRef]

37. Lodhi, A.; Ghauri, B.; Khan, M.R.; Rahman, S.; Shafique, S. Particulate matter $\left(\mathrm{PM}_{2.5}\right)$ concentration and source apportionment in Lahore. J. Bra. Chem. Soc. 2009, 20, 1811-1820. [CrossRef]

38. Mansha, M.; Ghauri, B.; Rahman, S.; Amman, A. Characterization and source apportionment of ambient air particulate matter $\left(\mathrm{PM}_{2.5}\right)$ in Karachi. Sci. Total Environ. 2012, 425, 176-183. [CrossRef] [PubMed]

39. Shahid, M.Z.; Liao, H.; Li, J.; Shahid, I.; Lodhi, A.; Mansha, M. Seasonal variations of aerosols in Pakistan: Contributions of domestic anthropogenic emissions and transboundary transport. Aerosol Air Qual. Res. 2015, 15, 1580-1600. [CrossRef]

40. Shahid, M.Z.; Hong, L.; Yu-Lu, Q.; Shahid, I. Source sector contributions to aerosol levels in Pakistan. Atmos. Ocean. Sci. Lett. 2015, 8, 308-313.

41. Alam, K.; Trautmann, T.; Blaschke, T.; Majid, H. Aerosol optical and radiative properties during summer and winter seasons over Lahore and Karachi. Atmos. Environ. 2012, 50, 234-245. [CrossRef]

42. Mitra, A.P.; Sharma, C. Global Environmental Changes in South Asia: A Regional Perspective; Springer Science \& Business Media: New York, NY, USA, 2012.

43. Khan, N. Marine Resources in Pakistan: A Tentative Inventory. Available online: http:/ / sustainableinitiatives.org.pk/da/Government\%20Documents/Research\%20Doucment/Marine\% 20Resources\%20In\%20Pakistan\%20NIO.pdf (accessed on 29 February 2016).

44. Haider, K.; Shah, S.M.R.; Ghaffar, B.; Naeem, S. Estimating the potential habitat of coral reefs along the coastline of Pakistan using GIS and RS techniques. Int. J. Fauna Biol. Stud. 2015, 2, 92-95.

45. Chaudhry, Q.-Z.; Mahmood, A.; Rasul, G.; Afzaal, M. Climate Change Indicators of Pakistan; Technical Report No. PMD-22/2009. Pakistan Meteorological Department: Islamabad, Pakistan, August 2009.

46. Naheed, G.; Kazmi, D.; Rasul, G. Seasonal variation of rainy days in Pakistan. Pak. J. Meteorol. 2013, 9, 9-13.

47. Ahmad, I.; Zhaobo, S.; Weitao, D.; Ambreen, R. Trend analysis of January temperature in Pakistan over the period of 1961-2006: Geographical perspective. Pak. J. Meteorol. 2010, 7, 11-22.

48. Hui, F.; Ci, T.; Cheng, X.; Scambos, T.A.; Liu, Y.; Zhang, Y.; Chi, Z.; Huang, H.; Wang, X.; Wang, F. Mapping blue-ice areas in Antarctica using ETM+ and MODIS data. Ann. Glaciol. 2014, 55, 129-137. [CrossRef]

49. Levy, R.; Mattoo, S.; Munchak, L.; Remer, L.; Sayer, A.; Hsu, N. The collection 6 modis aerosol products over land and ocean. Atmos. Meas. Tech. Discuss 2013, 6, 159-259. [CrossRef]

50. Veihelmann, B.; Veefkind, J.; Braak, R.; Levelt, P.; de Haan, J. Aerosol properties from omi using the multi-wavelength algorithm. In Proceedings of the 2007 ESA Envisat Symposium, Montreux, Switzerland, 23-27 April 2007.

51. Winker, D.M.; Pelon, J.R.; McCormick, M.P. The CALIPSO mission: Spaceborne lidar for observation of aerosols and clouds. In Proceedings of the Third International Asia-Pacific Environmental Remote Sensing Remote Sensing of the Atmosphere, Ocean, Environment, and Space, Hangzhou, China, 24 March 2003; pp. 1-11.

52. Cesnulyte, V.; Lindfors, A.; Pitkänen, M.; Lehtinen, K.; Morcrette, J.-J.; Arola, A. Comparing ECMWF AOD with AERONET observations at visible and UV wavelengths. Atmos. Chem. Phys. 2014, 14, 593-608. [CrossRef]

53. Gupta, P.; Khan, M.N.; da Silva, A.; Patadia, F. Modis aerosol optical depth observations over urban areas in Pakistan: Quantity and quality of the data for air quality monitoring. Atmos. Pollut. Res. 2013, 4, 43-52. [CrossRef]

54. Ali, M.; Tariq, S.; Mahmood, K.; Daud, A.; Batool, A.; Haq, Z. A study of aerosol properties over lahore (Pakistan) by using aeronet data. Asia-Pac. J. Atmos. Sci. 2013, 50, 153-162. [CrossRef]

55. Torres, O.; Jethva, H.; Bhartia, P. Retrieval of aerosol optical depth above clouds from omi observations: Sensitivity analysis and case studies. J. Atmos. Sci. 2012, 69, 1037-1053. [CrossRef] 
56. De Graaf, M.; Stammes, P.; Torres, O.; Koelemeijer, R. Absorbing aerosol index: Sensitivity analysis, application to gome and comparison with toms. J. Geophys. Res. Atmos. 2005, 110. [CrossRef]

57. Jaffe, D.; Bertschi, I.; Jaeglé, L.; Novelli, P.; Reid, J.S.; Tanimoto, H.; Vingarzan, R.; Westphal, D.L. Long-range transport of siberian biomass burning emissions and impact on surface ozone in Western North America. Geophys. Res. Lett. 2004, 31. [CrossRef]

58. Nedelec, P.; Thouret, V.; Brioude, J.; Sauvage, B.; Cammas, J.P.; Stohl, A. Extreme CO concentrations in the upper troposphere over northeast Asia in June 2003 from the in situ MOZAIC aircraft data. Geophys. Res. Lett. 2005, 32. [CrossRef]

59. Khokhar, M.F.; Khalid, T.; Yasmin, N.; De Smedt, I. Spatio-temporal analyses of formaldehyde over Pakistan by using SCIAMACHY and GOME-2 observations. Aerosol Air Qual. Res. 2015, 15, 1760-1773. [CrossRef]

60. Lall, J.S.; Moddie, A.D. Himalaya, Aspects of Change; Oxford University Press: New York, NY, USA, 1981.

61. Venkataraman, C.; Habib, G.; Eiguren-Fernandez, A.; Miguel, A.H.; Friedlander, S.K. Residential biofuels in South Asia: Carbonaceous aerosol emissions and climate impacts. Science 2005, 307, 1454-1456. [CrossRef] [PubMed]

62. Nair, V.S.; Moorthy, K.K.; Alappattu, D.P.; Kunhikrishnan, P.K.; George, S.; Nair, P.R.; Babu, S.S.; Abish, B.; Satheesh, S.K.; Tripathi, S.N.; et al. Wintertime aerosol characteristics over the Indo-Gangetic plain (IGP): Impacts of local boundary layer processes and long-range transport. J. Geophys. Res. Atmos. 2007, 112. [CrossRef]

63. Kaskaoutis, D.G.; Houssos, E.E.; Goto, D.; Bartzokas, A.; Nastos, P.T.; Sinha, P.R.; Kharol, S.K.; Kosmopoulos, P.G.; Singh, R.P.; Takemura, T. Synoptic weather conditions and aerosol episodes over indo-gangetic plains, india. Clim Dyn 2014, 43, 2313-2331. [CrossRef]

64. Ganguly, D.; Jayaraman, A.; Rajesh, T.A.; Gadhavi, H. Wintertime aerosol properties during foggy and nonfoggy days over urban center Delhi and their implications for shortwave radiative forcing. J. Geophys. Res. Atmos. 2006, 111. [CrossRef]

65. Mehta, B.; Venkataraman, C.; Bhushan, M.; Tripathi, S.N. Identification of sources affecting fog formation using receptor modeling approaches and inventory estimates of sectoral emissions. Atmos. Environ. 2009, 43, 1288-1295. [CrossRef]

66. Ahmad, S.; Majeed, R. Indus basin irrigation system water budget and associated problems. J. Eng. Appl. Sci. 2001, 20, 69-77.

67. Kaskaoutis, D.G.; Sinha, P.R.; Vinoj, V.; Kosmopoulos, P.G.; Tripathi, S.N.; Misra, A.; Sharma, M.; Singh, R.P. Aerosol properties and radiative forcing over Kanpur during severe aerosol loading conditions. Atmos. Environ. 2013, 79, 7-19. [CrossRef]

68. Crutzen, P.J.; Andreae, M.O. Biomass burning in the tropics: Impact on atmospheric chemistry and biogeochemical cycles. Science 1990, 250, 1669-1678. [CrossRef] [PubMed]

69. Active Fire Data (MCD14DL). Available online: https://earthdata.nasa.gov/earth-observation-data/nearreal-time/firms/active-fire-data (accessed on 29 February 2016).

70. Olivier, J.; Bouwman, A.; Van der Hoek, K.; Berdowski, J. Global air emission inventories for anthropogenic sources of $\mathrm{NO}_{x}, \mathrm{NH}_{3}$ and $\mathrm{N}_{2} \mathrm{O}$ in 1990. Environ. Pollut. 1998, 102, 135-148. [CrossRef]

71. Veefkind, J.P.; Boersma, K.; Wang, J.; Kurosu, T.; Krotkov, N.; Chance, K.; Levelt, P. Global satellite analysis of the relation between aerosols and short-lived trace gases. Atmos. Chem. Phys. 2011, 11, 1255-1267. [CrossRef]

72. Ichoku, C.; Chu, D.A.; Mattoo, S.; Kaufman, Y.J.; Remer, L.A.; Tanré, D.; Slutsker, I.; Holben, B.N. A spatio-temporal approach for global validation and analysis of modis aerosol products. Geophys. Res. Lett. 2002, 29. [CrossRef]

73. Streets, D.G.; Canty, T.; Carmichael, G.R.; de Foy, B.; Dickerson, R.R.; Duncan, B.N.; Edwards, D.P.; Haynes, J.A.; Henze, D.K.; Houyoux, M.R. Emissions estimation from satellite retrievals: A review of current capability. Atmos. Environ. 2013, 77, 1011-1042. [CrossRef]

74. Ichoku, C.; Kahn, R.; Chin, M. Satellite contributions to the quantitative characterization of biomass burning for climate modeling. Atmospheric Research 2012, 111, 1-28. [CrossRef]

75. Khattak, P.; Khokhar, M.F.; Yasmin, N. Spatio-temporal analyses of atmospheric sulfur dioxide column densities over Pakistan by using sciamachy data. Aerosol Air Qual. Res. 2014, 14, 1883-1896. [CrossRef]

76. Ramanathan, V.; Chung, C.; Kim, D.; Bettge, T.; Buja, L.; Kiehl, J.T.; Washington, W.M.; Fu, Q.; Sikka, D.R.; Wild, M. Atmospheric brown clouds: Impacts on South Asian climate and hydrological cycle. Proc. Natl. Acad. Sci. USA 2005, 102, 5326-5333. [CrossRef] [PubMed] 
77. Lau, K.M.; Kim, M.K.; Kim, K.M. Asian summer monsoon anomalies induced by aerosol direct forcing: The role of the Tibetan plateau. Clim. Dyn. 2006, 26, 855-864. [CrossRef]

78. Qian, Y.; Flanner, M.G.; Leung, L.R.; Wang, W. Sensitivity studies on the impacts of Tibetan plateau snowpack pollution on the Asian hydrological cycle and monsoon climate. Atmos. Chem. Phys. 2011, 11, 1929-1948. [CrossRef]

79. Yasunari, T.J.; Bonasoni, P.; Laj, P.; Fujita, K.; Vuillermoz, E.; Marinoni, A.; Cristofanelli, P.; Duchi, R.; Tartari, G.; Lau, K.M. Estimated impact of black carbon deposition during pre-monsoon season from Nepal climate observatory-Pyramid data and snow albedo changes over Himalayan glaciers. Atmos. Chem. Phys. 2010, 10, 6603-6615. [CrossRef]

80. Gautam, R.; Hsu, N.C.; Lau, W.K.M.; Yasunari, T.J. Satellite observations of desert dust-induced Himalayan snow darkening. Geophys. Res. Lett. 2013, 40, 988-993. [CrossRef]

81. Cams. Available online: http://iridl.ldeo.columbia.edu/maproom/Global/Atm_Temp/Anomaly.html (accessed on 29 February 2016).

82. Ohara, T.; Akimoto, H.; Kurokawa, J.; Horii, N.; Yamaji, K.; Yan, X.; Hayasaka, T. An Asian emission inventory of anthropogenic emission sources for the period 1980-2020. Atmos. Chem. Phys. 2007, 7, 4419-4444. [CrossRef]

83. Hsu, N.C.; Gautam, R.; Sayer, A.M.; Bettenhausen, C.; Li, C.; Jeong, M.J.; Tsay, S.C.; Holben, B.N. Global and regional trends of aerosol optical depth over land and ocean using seawifs measurements from 1997 to 2010. Atmos. Chem. Phys. 2012, 12, 8037-8053. [CrossRef]

84. Dimitris, G.K.; Ramesh, P.S.; Ritesh, G.; Manish, S.; Kosmopoulos, P.G.; Tripathi, S.N. Variability and trends of aerosol properties over kanpur, northern india using aeronet data (2001-10). Environ. Res. Lett. 2012, 7, 024003.

85. Babu, S.S.; Manoj, M.R.; Moorthy, K.K.; Gogoi, M.M.; Nair, V.S.; Kompalli, S.K.; Satheesh, S.K.; Niranjan, K.; Ramagopal, K.; Bhuyan, P.K.; et al. Trends in aerosol optical depth over Indian region: Potential causes and impact indicators. J. Geophys. Res. Atmos. 2013, 118, 11794-11806. [CrossRef]

86. Ahrens, C.D. Meteorology Today: An Introduction to Weather, Climate, and the Environment; Cengage Learning: Belmont, CA, USA, 2012.

87. Visibility Data. Available online: http://www.weatherforyou.com/reports/index.php (accessed on 29 February 2016).

88. Pak-NEQS: Paksitan's National Environmental Quality Standards. Available online: http:/ /environment. gov.pk/NEQS/SRO-2010-NEQS\%20Air-Water-Noise.pdf (accessed on 29 February 2016).

89. Xia, X.; Chen, H.; Wang, P.; Zhang, W.; Goloub, P.; Chatenet, B.; Eck, T.; Holben, B. Variation of column-integrated aerosol properties in a Chinese urban region. J. Geophys. Res. Atmos. 2006, 111. [CrossRef]

90. Zha, Y.; Gao, J.; Jiang, J.; Lu, H.; Huang, J. Monitoring of urban air pollution from modis aerosol data: Effect of meteorological parameters. Tellus B 2010, 62, 109-116. [CrossRef]

91. Han, Y.; Wu, Y.; Wang, T.; Zhuang, B.; Li, S.; Zhao, K. Impacts of elevated-aerosol-layer and aerosol type on the correlation of aod and particulate matter with ground-based and satellite measurements in Nanjing, southeast china. Sci. Total Environ. 2015, 532, 195-207. [CrossRef] [PubMed]

92. Li, R.; Gong, J.; Chen, L.; Wang, Z. Estimating ground-level pm 2.5 using fine-resolution satellite data in the megacity of Beijing, China. Aerosol Air Qual. Res. 2015, 15, 1347-1356. [CrossRef]

93. Rolph, G. Real-Time Environmental Applications and Display System; NOAA Air Resources Laboratory: Silver Spring, MD, USA, 2003.

94. Rolph, G.; Ngan, F.; Draxler, R. Modeling the fallout from stabilized nuclear clouds using the hysplit atmospheric dispersion model. J. Environ. Radioact. 2014, 136, 41-55. [CrossRef] [PubMed]

95. Stein, A.; Draxler, R.; Rolph, G.; Stunder, B.; Cohen, M.; Ngan, F. NOAA'S hysplit atmospheric transport and dispersion modeling system. Bull. Am. Meteorol. Soc. 2015, 96, 2059-2077. [CrossRef]

(C) 2016 by the authors; licensee MDPI, Basel, Switzerland. This article is an open access article distributed under the terms and conditions of the Creative Commons Attribution (CC-BY) license (http:/ / creativecommons.org/licenses/by/4.0/). 